\title{
Massively parallel sequencing of formalin-fixed paraffin-embedded tissues
}

\author{
Rachel L Erlich*, Emanuele Palescandolo, Robert T Jones, Ashwini Sunkavalli, Alina Raza, Matthew Ducar, \\ Charles Hatton, Christina Go, Christine Roden, Megan Hanna, Adri Mills, Ravali Adusumilli, Prateek Kumar, \\ Priscilla K Brastianos, Matthew L Meyerson, William C Hahn, Laura E MacConaill, Paul Van Hummelen
}

From Beyond the Genome 2012

Boston, MA, USA. 27-29 September 2012

Formalin fixation followed by paraffin embedment (FFPE) is the most common method of preserving resected tissues. FFPEs can be easily stored, retrieved and processed for further analysis when compared to the logistical complications of processing fresh frozen (FF) material. Conversely, they may not be ideal for sequencing because of the nucleic acid fragmentation and artifacts introduced by fixation. Here we report our efforts in performing next-generation sequencing on more than 70 specimens comprising $>40$ FFPE samples, from low to high quality, and compared the performance of FFPE, FF and commercially available cell lines.

Published: 1 October 2012

Cite this article as: Erlich et al:: Massively parallel sequencing of

formalin-fixed paraffin-embedded tissues. BMC Proceedings 2012

6(Suppl 6):P40.

Dana-Farber Cancer Institute, Boston, Massachusetts 02115, USA

Submit your next manuscript to BioMed Central and take full advantage of:

- Convenient online submission

- Thorough peer review

- No space constraints or color figure charges

- Immediate publication on acceptance

- Inclusion in PubMed, CAS, Scopus and Google Scholar

- Research which is freely available for redistribution

Submit your manuscript at www.biomedcentral.com/submit

\section{() Biomed Central}

\section{Biomed Central}

